Article available at nttp://WWW.parasite-|ournal.org or nitp://dx.dol.org/10.1051/parasite/1995021037

\title{
Purification of a fraction of Giardia lamblia trophozolte EXTRACT ASSOCIATED WITH DISACCHARIDASE DEFICIENCIES IN IMMUNE MONGOLIAN GERBILS (MERIONES UNGUICULATUS)
}

\author{
MOHAMMED S.R.* \& FAUBERT G.M.*
}

\section{Summary :}

The effects on disaccharidase activities of challenging gerbils previously exposed to Giardia lamblia with fradions of the crude trophozoite extract were examined. Gel filtration of the soluble extract on a Sephacryl S-200 HR column resulted in 3 fradions F1, F2 and F3. Only a challenge with fraction F1 $10.1 \mathrm{mg}$ total dosel was found to induce disaccharidase deficiencies. Boiling F I prior to challenge did not change this effect on the enzyme activities. However, the decreases were nol obtained when the total F 1 dose was reduced to $0.05 \mathrm{mg}$. Column chromatography of fraction $\mathrm{F} 1$ under dissociating and reducing conditions resulted in 2 further fractions: Fla and Flb. Challenging immune gerbils with Flb led to impairments of disaccharidase activity similar to those obtained with Fl. Protein analysis of the crude extract, as well as the fractions of the extract, revealed several high and low molecular weight bands. These findings indicate that a constituent(s) of fraction Flb is the portion of the parasite which induces disaccharidase deficiencies in immune gerbils. This fraction consists of proteins ranging in molecular weight from 32 to $200 \mathrm{kDa}$. In addilion the $G$. lamblia fraction involved in the decreases in enzyme activity is heat-stable.

KEY WORDS : Giardia lamblia. disaccharidase. Mongolian gerbils. column chromatography. gel filtration. immunity.

MOTS CLES : Giardia lamblia. disaccharidase. gerboises mongoliennes. filtration sur gel. colonne de chromatographie. immunité.

\section{INTRODUCTION}

Tiardia lamblia is a common cause of diar rhea in day-care centres, institutionalized persons, homosexuals and travellers (Keystone et al., 1978; Brodsky et al., 1974; Schmerin et al., 1978). This flagellated, binucleate parasite adheres to the brush border of the host's enterocytes by means of a ventral sucking disk. Many giardial infections are well tolerated and asymptomatic in human patients. However, when illness is evident, the spectrum of symptoms is wide and ranges from acute, self-limiting gastroenteritis to protracted and debilitating malabsorption (Shandera, 1990).

\footnotetext{
* Institute of Parasitology of McGill University, Macdonald Campus, 21,111 Lakeshore Road, Ste. Anne de Bellevue, Québec, Canada H9X 3 V9.

Correspondence : Dr. G.M. Faubert, Tel. : (514) 398-7724; Fax (514) 398-7857. E. mail : GAETAN @ PARASIT.LAN.MCGILL.CA.
}

Résumé : PURIFICATION D'UNE FRACTION DE TROPHOZOÏTES DE GIARDIA LAMBLIA LIÉE À UNE DIMINUTION DE L'ACTIVITÉ DES DISACCHARIDASES CHEZ LE MÉrion (MERIONES UNGUICULATUS) IMMUNISÉ

Les effets de l'inoculation de fractions de trophozoïtes de Giardia lamblia sur les activités disaccharidasiques chez les gerboises mongoliennes précédemment infectées avec $\mathrm{G}$. lamblia ont été étudiés. La filtration sur gel Sephacryl S-200 HR a produit 3 fractions : Fl F2 et F3. La fraction Fl est la seule qui ait réduit l'activité des disaccharidases lors d'une dose de rappel (de $0,1 \mathrm{mg}$ ). la fraction Fl, amenée à son point d'ébullition, conserve son effet négatif sur l'activité des enzymes. Toutefois, l'activité enzymatique n'est plus affectée par Fl lorsque celle-ci est réduite jusqu'à 0,05 mg. La chromatographie sur colonne de la fraction Fl dans des conditions de dissociation et de réduction a mené à 2 autres fractions: Fla et Flb. Utilisée en dose de rappel chez les gerboises précédemment infectées, la fraction Flb a produit des effets similaires à ceux de F 7 sur l'activité des enzymes. L'onalyse protéique de l'extrait complet des trophozoiltes et des fractions obtenues par chromatographie révèle plusieurs bandes de poids moléculaires variés. Ces résultats indiquent que la fraction de Giardia responsable de la déficience de l'activité des disacchanidases est localisée dans la fraction FIb. Le poids moléculaire des protéines de cette fraction varie de 32 à 200 kDa. De plus, la fraction de G. Iamblia qui est liée à la diminution des activités disaccharidasiques est stable à la chaleur.

In giardiasis, it has been established that there can be considerable malfunctioning of the epithelium of the small intestine. For example, fat and vitamin B12 malabsorption has been described in human giardiasis (Hoskins et al., 1967; Wright et al., 1977). Vitamin A deficiency has been found in children infected with G. lamblia (Mahalanabis et al., 1979). Also, temporary disaccharidase deficiencies have been well documented in this disease. Buret and co-workers (1990) reported decreases in maltase and sucrase activities in mice, following a primary infecdon with G. muris. It was suggested that these disaccharidase deficiencies were due to a diffuse shortening of brush border microvilli. Studies on G. lamblia infections in mice found decreases in several brush border enzymes throughout the course of infection (Nain et al., 1991). The degree of decline in these enzyme activities correlated well with the number of trophozoites in the jejunum, with the most severe reductions in enzyme activity occurring during the peak phase of infection. 
Using the gerbil animal model, Belosevic and colleagues (1989) observed decreases in disaccharidase activity during both primary and challenge infecdons with G. lamblia. The involvement of the host's immune response in the deficiencies was suggested by the ability of a crude extract of the trophozoites to induce these impairments of enzyme activity in immune gerbils (Belosevic et al., 1989). Recent work in our laboratory has confirmed these previous findings (manuscript in preparadon). We also showed that the effect of the extract on disaccharidase activity is dose-dependent.

However, the component(s) of the G. lamblia crude extract involved in the disaccharidase deficiencies, as well as the mechanism(s) leading to such reductions in enzyme activity, are unknown. G. lamblia is considered to be antigenically complex, yet little is known about the structures and properdes of these antigens (Chaudhuri et al., 1988).

Cevallos and Farthing (1992) reported a strain-dependent reducdon in disaccharidase acdvities in G. lamblia-infected rats. The antigenic differences between these strains rnay have led to the variable effects on the enzyme activities. The present study was undertaken in order to purify the G. lamblia crude antigen extract and identify the specific fraction responsible for inducing the disaccharidase deficiencies observed in immune gerbils. In addition, we undertook an initial characterization of this fraction. This work shows that a specific fraction of the $G$. lamblia crude extract can be linked to the disaccharidase deficiencies in immune gerbils. This fraction is heat-stable and affects the enzyme activities with a threshold limit.

\section{MATERIALS AND METHODS}

\section{PARASITES}

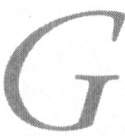

7. lamblia trophozoites, WB strain (American Type Culture Collection $n^{\circ} 30957$ ), originally isolated from a symptomatic patient (Smith et al., 1982), were used throughout this study. Trophozoites were cultured axenically in filter-sterilized TYI-S33 (trypticase, yeast extract, iron, and serum) medium adapted for G. lamblia (Gillin and Diamond, 1979), with 10\% adult bovine serum (Sigma Chemical Co., St. Louis, U.S.A.), and supplemented with 100 units $/ \mathrm{ml}$ of penicillin (Sigma) and $100 \mathrm{~g} / \mathrm{ml}$ of dihydrostreptomycin sulphate salt (Sigma), in the absence of bovine bile. The trophozoites were passaged twice weekly.

\section{Animals}

Six to 10 week old male Mongolian gerbils (Meriones ungukulatus), originating from Tumblebrook Farms
(West Brookfield, U.S.A.), were used in this study. They were maintained under standard laboratory conditions and provided with laboratory chow and water ad libitum. One week after arrival, gerbils were each treated with $15 \mathrm{mg}$ of metronidazole (RhônePoulenc, Montreal, Canada), by oral gavage, for three consecutive days and then allowed to rest for 10 days. This treatment was done to ensure that the gerbils were free of intestinal infections. All inoculations were done orally, to unanaesthetized gerbils. In the primary infection, each gerbil was inoculated with $1 \times$ $10^{6}$ live G. lamblia trophozoites.

\section{Preparation of the CRUde EXTRACT OF $G$. LAM-}

\section{BLIA TROPHOZOITES}

Trophozoites (from a 72 -h culture) were dislodged from the walls of culture vessels by immersion in an ice bath for 15-30 min. They were sedimented by centrifugadon at $800 \mathrm{~g}$ for $10 \mathrm{~min}$, at $4{ }^{\circ} \mathrm{C}$, and washed 5 times in sterile phosphate-buffered saline (PBS) (pH 7.2). Trophozoites, suspended in sterile PBS, were then lysed by discontinuous sonicadon in an ice bath, using a Sonic Dismembrator (Fisher Scientific, Montreal, Canada) at maximum output, for $10 \mathrm{~min}$. The sonicated material was cleared of insoluble matter by centrifuging at $23,300 \mathrm{~g}$ for $20 \mathrm{~min}$, at $4^{\circ} \mathrm{C}$, and the supematant colleaed as the crude soluble extract.

\section{COLUMN CHROMATOGRAPHY}

Samples were fractionated by gel filtradon chromatography. For this purpose, approximately $80 \mathrm{ml}$ of preswollen Sephacryl S-200 HR gel (Pharmacia LKB Biotechnology, Uppsala, Sweden), wet bead diameter 25-75 $\mu \mathrm{m}$, were packed into a $1.8 \times 50 \mathrm{~cm}$ glass column (Bio-Rad, Mississauga, Canada). The void volume of the column was determined by applying Blue Dextran 2000 and the column calibrated with known molecular weight (MW) marker of gel filtration proteins (Pharmacia). For each run, at $4{ }^{\circ} \mathrm{C}, 1-2 \mathrm{ml}$ of sample (with $10 \%$ glycerol) was applied to the gel bed and a flow rate of $5 \mathrm{ml} / \mathrm{h}$ maintained using a peristaldc pump (Pharmacia). Fractions of $2 \mathrm{ml}$ each were collected and an eluction profile obtained by measuring the optical density (O.D.) at $280 \mathrm{~nm}$ and plotting these values against the fraction numbers. According to the O.D. values, each peak and trailing eluates were pooled separately. These pooled fractions were then dialyzed, using Spectra/Por 6 Membrane (MW Cut-Off : 1000) (Spectrum Medical Industries Inc., Los Angeles, U.S.A.), against distilled water for $24 \mathrm{~h}$, at $4{ }^{\circ} \mathrm{C}$. Following dialysis, fractions were lyophilized and resuspended in PBS at a concentration of $\sim 0.3 \mathrm{mg} / \mathrm{ml}$. The fractions were stored at $-70{ }^{\circ} \mathrm{C}$ until used. 
SODIUM DODECYL SULFATE-POLYACRYLAMIDE GEL ELECTROPHORESIS (SDS-PAGE)

Samples were electrophoresed in a Mini-PROTEAN II vertical slab cell (Bio-Rad) using the discontinuous system of Laemmli (1970). Protein samples were separated through a $4 \%$ stacking gel and 10\% separating gel. Bio-Rad molecular weight standards were run simultaneously. The gel was stained with $0.25 \%$ Coomassie Brilliant Blue R-250 dye (Bio-Rad).

\section{MEASUREMENT OF INTESTINAL DISACCHARIDASES}

Preparation of intestinal homogenate

Hornogenates were prepared as previously described by Belosevic and colleagues (1989), with modifications. Briefly, the gerbils were killed and the small intestine removed and divided into three sections. The segments were placed in ice cold distilled water and each was flushed with $50 \mathrm{ml}$ of distilled water to clear it of intestinal debris. The segments were then slit longitudinally and the mucosa scraped off with a glass microscope slide. The mucosa from all three secdons were combined, weighed (wet weight), and placed in four volurnes of ice cold distilled water. The mucosal scrapings were then homogenized using a Con Torque power unit at maximum speed (Eberbach Corp., Ann Arbor, U.S.A.). Homogenates were stored, without prior centrifugation, at $-70{ }^{\circ} \mathrm{C}$ undl used in the assay.

Assay for intestinal disaccharidases

Disaccharidase activity of homogenated mucosa was measured using the glucose oxidase peroxidase assay of Dahlquist (1968), as modified by Belosevic et al. (1989), which is based on a colour reaction with the glucose liberated by a specific disaccharidase in 60 min. The assay consisted of adding to each well of a 96-well Nunc microwell plate (Gibco BRL, Burlington, Canada) $0.01 \mathrm{ml}$ of appropriately diluted mucosal sample (homogenate) and $0.01 \mathrm{ml}$ substrate-buffer solution of a disaccharidase to be measured, in quadruplicate. The plate was then incubated at $37^{\circ} \mathrm{C}$ in humidified atmosphere for $60 \mathrm{~min}$. After incubation, $0,3 \mathrm{ml}$ tris-glucose oxidase reagent was added to each well and the plate incubated for an additional $60 \mathrm{~min}$. The plate was then read at $415 \mathrm{~nm}$ using a Bio-Tek microplate reader (Mandel Scientific, Guelph, Canada). For each assay, eight wells of reagent blank and a glucose standard series $(2,6$, and $10 \mu \mathrm{g}$ glucose) in quadruplicate were also done. Disaccharidase activity is expressed as units/mg protein in the mucosal sample $(\mathrm{U} / \mathrm{mg})$, where units represent $\mu$ moles of disaccharide hydrolyzed $/ \mathrm{min}$.

\section{Reagents}

All chemicals were obtained commercially. D-(+)-
Glucose (G-8270), B-lactose (L-3750), maltose (M5885, D-(+)-trehalose (T-5251), maleic acid (M-0375), glucose oxidase (G-1262), o-dianisidine (D-9143), peroxidase (P-8000), and triton X-100 (T-6878) were purchased from Sigma. Sucrose (S5-3) was obtained from Fisher Scientific and tris (ultra pure - 819623) was purchased from ICN Biomedicals Canada Ltd. (St. Laurent, Canada).

\section{MEASUREMENT OF PROTEIN CONCENTRATION}

Protein concentrations were determined as described by Lowry et al. (1951), using $0.2 \mathrm{ml}$ of sample and a final reaction volume of $1.3 \mathrm{ml}$. For each protein assay, a standard cune was prepared using freshly dissolved bovine serum albumin (BSA).

\section{STATISTICAL ANALYSIS}

Statistical significance was determined using the Mann-Whitney $U$-test. Significance was assigned at the probability level of $\mathrm{P}<0.05$.

\section{RESULTS}

PuRIfication OF THE CRUde EXTRACT OF G. LAMBLIA TROPHOZOITES

he crude soluble extract of G. lamblia trophozoites was subjected to column chromatography using Sephacryl S-200 HR gel filtration in order to fractionate its components. Three light-absorbing $(280 \mathrm{~nm})$ peaks were observed, one of which appeared in the void volume, one in the middle as a shoulder of the first peak, and another at the end of total column volume (Fig. 1). Eluted materials were collected to give fractions $\mathrm{F} 1\left(>15 \times 10^{4} \mathrm{MW}\right), \mathrm{F} 2$ $\left(\sim 6.7 \times 10^{4} \mathrm{MW}\right)$, and $\mathrm{F} 3\left(<1.4 \times 10^{4} \mathrm{MW}\right)$, as indicated in Fig. 1. These were pooled from fractions 16-22, 23-29 and 34-43, respectively.

\section{Challenge With the FRactions of G. LAMBLLA SOLUBLE EXTRACT}

To determine whether any one of the fractions of the soluble extract (described above) could affect disaccharidase activity in gerbils previously exposed to $G$. lamblia, each animal was challenged with $0.1 \mathrm{mg}$ of F1, F2, or F3. The gerbils were challenged on day 50 post-infection (p.i.), which is well past the elimination of the parasite (around day 30 p.i.), as deterrnined by trophozoite counts from intestinal washings and fecal cyst release. The animals were not treated for the primary infection prior to challenging, since the age-matched control gerbils had also received the 

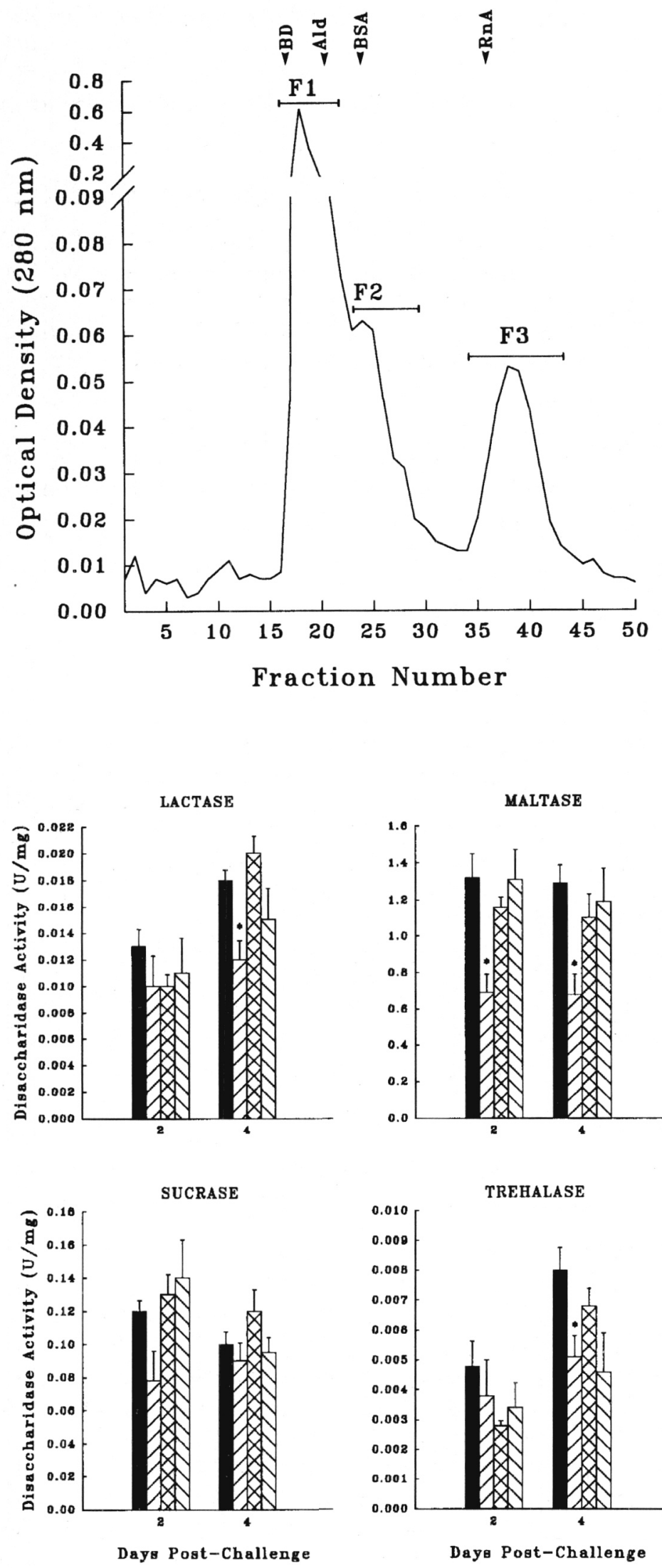

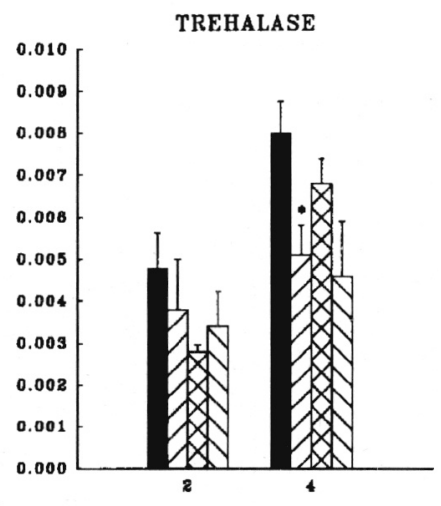

Dayg Post-Challenge
Fig. 1. - Chromatograph of the soluble extract of sonicated G. lamblia trophozoites.

Approximately $1.8 \mathrm{mg}$ of the soluble extract were run through a Sephacryl S-200 HR column at a flow rate of $5 \mathrm{ml} / \mathrm{h}$, using a buffer of $0.15 \mathrm{M} \mathrm{PBS}, 0.02 \%$ sodium azide ( $\mathrm{pH} 7.2)$. Fractions were collected and pooled to give F1, F2 and F3, as indicated. The column was calibrated with Blue Dextran 2000 (BD; > $200 \times 10^{4} \mathrm{MW}$ ), Aldolase (Ald; $15.8 \times 10^{4} \mathrm{MW}$ ), Bovine Serum Albumin (BSA; $\left.6.7 \times 10^{4} \mathrm{MW}\right)$, and Ribonuclease A (RnA; $1.4 \times$ $\left.10^{4} \mathrm{MW}\right)$.
Fig. 2. - Disaccharidase activities in gerbils challenged with different fractions of the soluble extract of $G$. lamblia trophozoites. Each gerbil was challenged with $0.1 \mathrm{mg}$ of F1 ( $\square)$, F2 ( $\otimes)$ or F3 ( $\square$ ( 50 days after a primary infection with $1 \times 10^{6}$ live trophozoites. Control gerbils ( $\mathbf{\square})$ were age-matched and received the primary infection, but were not challenged. Results are expressed as mean \pm s.e., $\mathrm{n}=4$ for unchallenged controls and $n=5$ for fraction-challenged groups.

* Differences between control and challenged groups were significant, $\mathrm{P}<0.05$. 
LACTASE

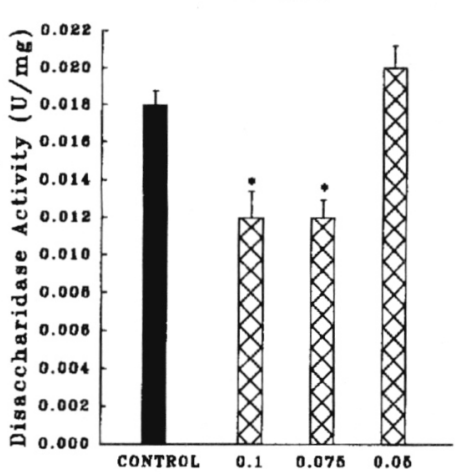

SUCRASE

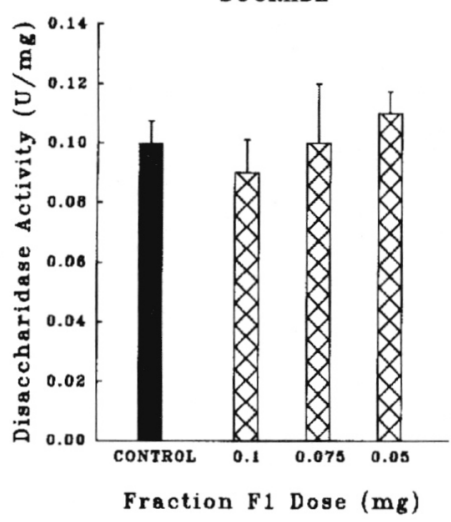

MALTASE

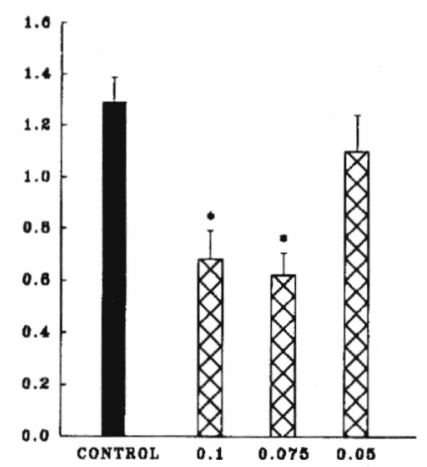

TREHALASE

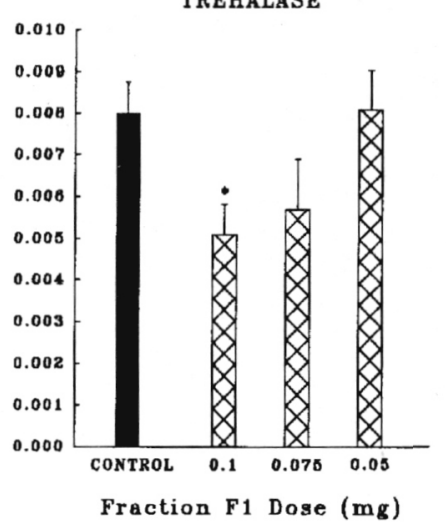

Fig. 3. - Disaccharidase activities in gerbils challenged with varying amounts of fraction F1. Gerbils were challenged 50 days following a primary infection with $1 \mathrm{x}$ 106 live trophozoites. Control gerbils were age-matched and received a primary infection, but were not challenged. Results are for day 4 post-challenge and are expressed as mean \pm s.e., $\mathrm{n}=4$ for unchallenged controls ( $\square$ ) and $\mathrm{n}=5$ for F1-challenged groups ( $\otimes$ ).

* Differences between control and challenged groups were significant, $\mathrm{P}<0.05$. primary inoculation. The activities of the enzymes lactase, maltase, sucrase, and trehalase were then measured on days 2 and 4 post-challenge (p.c.), as these were the days on which disaccharidase activity was affected during challenge inoculations with the whole crude extract (manuscript in preparation). As shown in Fig. 2, the activity of sucrase was not affected by any of the three fractions of the extract, as levels on both days 2 and 4 p.c. remained comparable to controls. Although the mean activity on day 2 p.c. in F1-challenged animals $(0.078 \pm 0.018 \mathrm{U} / \mathrm{mg})$ seemed to be lower than in the control $(0.12 \pm 0.0063 \mathrm{U} / \mathrm{mg})$, this difference was not significant as determined through statistical analysis. However, the activities of lactase, maltase, and trehalase were reduced by as much as $47 \%$ on day 4 p.c. in F1-challenged gerbils. In addition, an $\mathrm{F} 1$ challenge also led to a decrease in maltase activity on day 2 p.c. On the other hand, challenging immune gerbils with either fraction F2 or F3 had no effect on any of the disaccharidase activities.

In order to determine whether there was a threshold effect of fraction F1 on enzyme activities, immune gerbils were challenged with $0.075 \mathrm{mg}$ or $0.05 \mathrm{mg}$ total of F1. Disaccharidase activity was then measured on day 4 p.c., since this was the time when the most extensive effects on the enzymes were observed with the $0.1 \mathrm{mg}$ F1 challenge. Sucrase activity remained unaffected by this fraction of the soluble extract, regardless of the dosage (Fig. 3). However, lactase and maltase activities were significantly reduced with an F1 dose of $0.075 \mathrm{mg}$, compared to unchallenged controls. These decreases in disaccharidase activity were similar to the reduced levels observed in the gerbils challenged with $0.1 \mathrm{mg}$ of F1. There were no reductions in the activities of any of the four enzymes when a dose of $0.05 \mathrm{mg}$ was given to the animals.

In order to determine whether the portion of $\mathrm{F} 1$ responsible for inducing the disaccharidase deficiencies is heat-stable, it was boiled at $100{ }^{\circ} \mathrm{C}$ for $5 \mathrm{~min}$ and used to challenge infected gerbils. Decreases in lactase, maltase, and trehalase activities were detected on day 4 p.c., while sucrase activity did not significantly differ from control levels (data not shown). These findings were similar to those obtained with $\mathrm{F} 1$ which was not boiled and indicate that the G. lamblia fraction involved in the disaccharidase deficiencies is heat-stable.

\section{ISOLATION OF F1 SUB-FRACTIONS}

In order to further purify the fraction of the G. lamblia extract involved in the disaccharidase deficiencies, fraction F1 was subjected to gel filtration chromatography using a Sephacryl S-200 HR column. The dissociating agent guanidine HCI (Sigma) and the reducing agent DL-dithiothreitol (Sigma) were used as an eluent to disrupt non-covalent interactions and break disulfide bonds in fraction F1. Two peaks were observed, one of which eluted with the void volume 


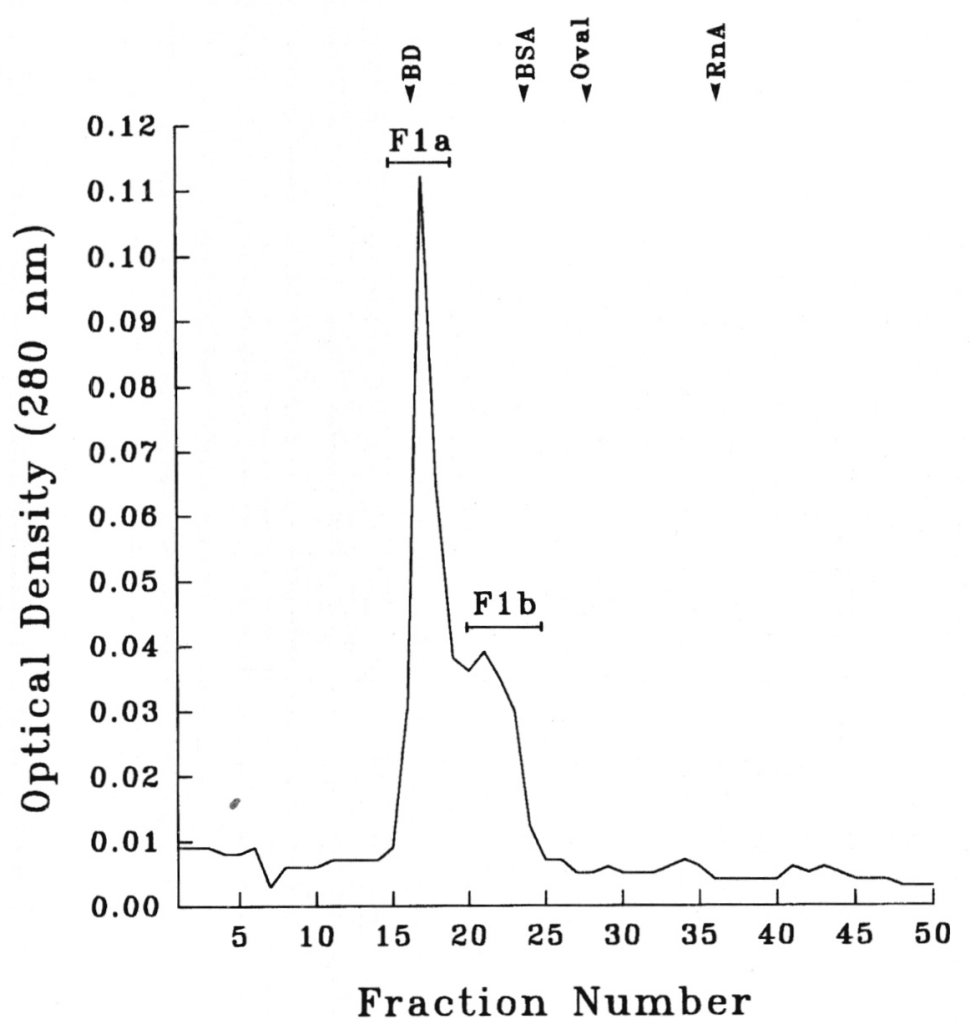

LACTASE

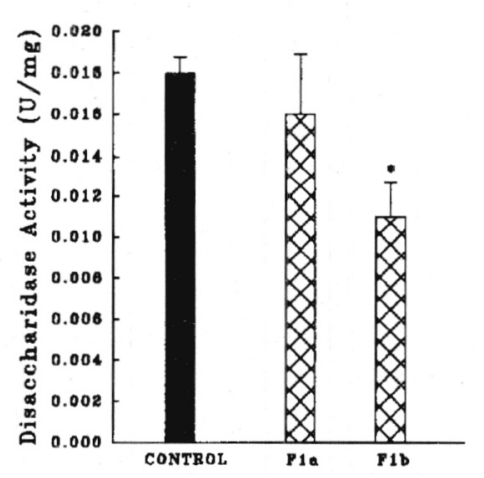

SUCRASE

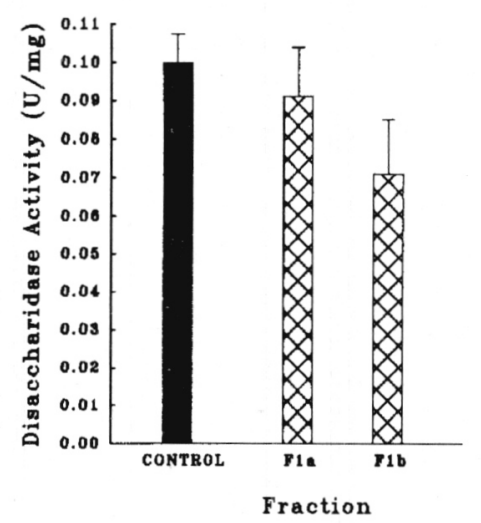

MALTASE

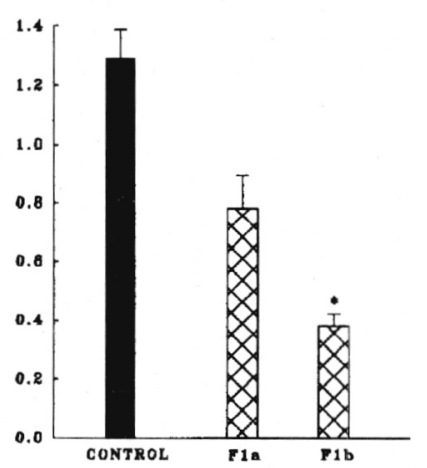

TREHALASE

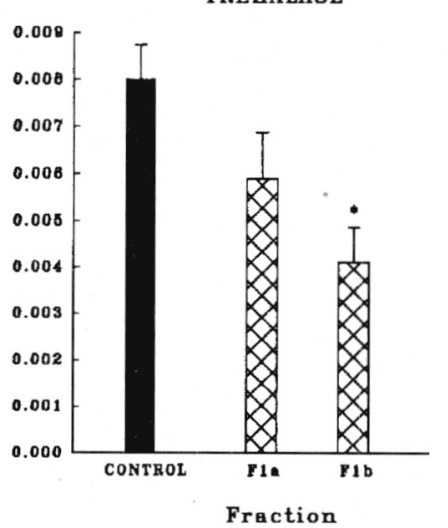

Fig. 4. - Chromatograph of fraction F1. Approximately $2 \mathrm{mg}$ of $\mathrm{F} 1 \mathrm{were}$ applied on a Sephacryl S-200 HR column $(1.8 \times 50 \mathrm{~cm})$ at a flow rate of $5 \mathrm{ml} / \mathrm{h}$. The eluent consisted of $2 \mathrm{M}$ guanidine- $\mathrm{HCl}, 2.5 \mathrm{mM}$ dithiothreitol and $0.02 \%$ sodium azide, in PBS ( $\mathrm{pH} 7.2$ ). Fractions were collected and pooled to give F1a and F1b, as indicated. The column was calibrated with Blue Dextran 2000 (BD; > $\left.200 \times 10^{4} \mathrm{MW}\right)$, Bovine Serum Albumin (BSA; $6.7 \times 10^{4} \mathrm{MW}$ ), and Ribonuclease A (RnA; $\left.1.4 \times 10^{4} \mathrm{MW}\right)$.

Fig. 5. - Disaccharidase activities in gerbils challenged with fractions F1a and F1b. Gerbils were each challenged with $0.1 \mathrm{mg}$ of F1a or F1b 50 days following a primary infection with $1 \times 10^{6}$ live trophozoites. Control gerbils were age-matched and received a primary infection, but were not challenged. Results are for as mean \pm s.e., $n$ $=4$ for unchallenged controls $(\mathbf{a})$ and $\mathrm{n}=5$ for F1a/F1b challenged groups (囚). " Differences between control and challenged groups were significant, $\mathrm{P}<0.05$. 


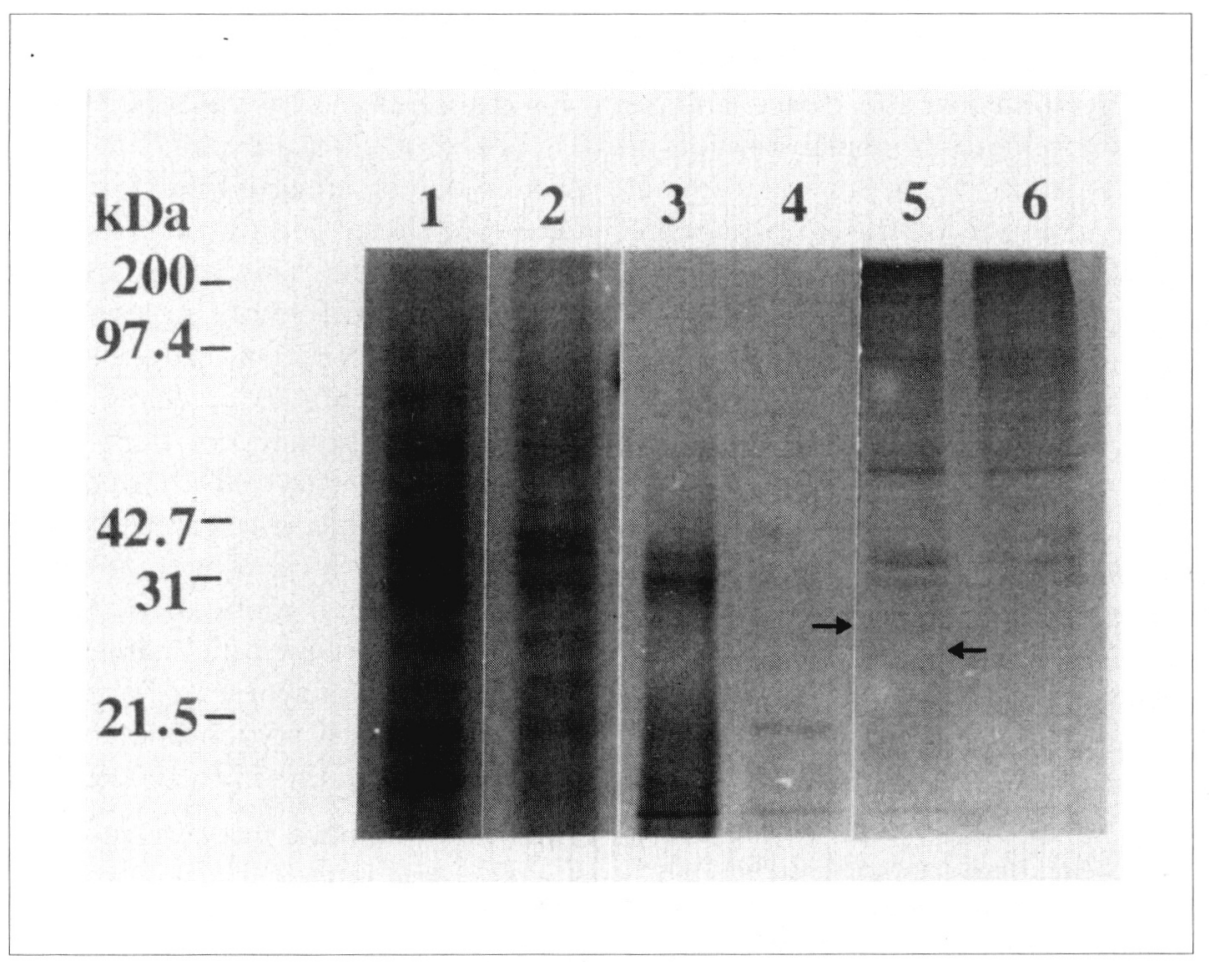

Fig. 6. - SDS-PAGE of crude extract of G. lamblia trophozoites and partially purified fractions of the extract. The gel was stained with Coomassie brilliant blue R-250. Molecular weight standards are shown on the left. Lane 1 : crude extract; $2: \mathrm{F} 1 ; 3: \mathrm{F} 2 ; 4: \mathrm{F} 3 ; 5: \mathrm{F} 1 \mathrm{a} ; 6:$ F1b.

$\left(\sim 200 \times 10^{4} \mathrm{MW}\right)$ and the other appeared in the high molecular veight $\left(>6.7 \times 10^{4} \mathrm{MW}\right)$ region of the separation (Fig. 4). Fractions 15-19 and 20-25 were collected separately to give pooled fractions F1a and F1b, respectively.

\section{Challenge With Fractions F1A AND F1B}

To determine whether disaccharidase activity could be affected by one of the fractions of F1, immune gerbils were each challenged with a total of $0.1 \mathrm{mg}$ of either F1a or F1b. Enzyme activities were then measured on day 4 p.c. The activities of all four enzymes remained comparable to control levels in F1a-challenged animals (Fig. 5). However, challenging with fraction $\mathrm{F} 1 \mathrm{~b}$ resulted in significant decreases in the activities of lactase, maltase, and trehalase. These reductions ranged from $39 \%$ to $71 \%$. Although sucrase activity seemed to be lowered by an F1b challenge $(0.071 \pm 0.014 \mathrm{U} / \mathrm{mg}$ compared to a control level of $0.1 \pm 0.0075 \mathrm{U} / \mathrm{mg}$ ), this difference was not significant given the sample sizes.

\section{SDS-PAGE}

In order to determine whether there are proteins unique to the fractions affecting enzyrne activity, the protein profiles of the crude extract and of the partially purified extract fractions were compared follo- wing SDS-PAGE. Several high and low molecular weight bands were seen (Fig. 6). The crude extract (lane 1) showed approximately 20 discernable protein bands, with molecular weights ranging from 14 to $130 \mathrm{kDa}$. However, the banding pattern of fraction F1 (lane 2) was in the 25 to $200 \mathrm{kDa}$ range and F2 (lane 3) was in the smaller region of 30 to $55 \mathrm{kDa}$. Fraction F3 (lane 4) showed only one protein band, of $20 \mathrm{kDa}$. For both F1a (lane 5) and F1b (lane 6), a number of bands were detected, mainly in the molecular weight region of 32 to $200 \mathrm{kDa}$. However, there were two discrete bands seen in fraction F1a which were absent from F1b. These had molecular masses of $25 \mathrm{kDa}$ and $27 \mathrm{kDa}$ (arrows, lane 5). In addition, major bands of $30 \mathrm{kDa}$ and $37 \mathrm{kDa}$ were seen in all samples, with the exception of fraction F3. Both fractions which were implicated in the disaccharidase deficiencies - F1 and F1b - showed several proteins in common with the other fractions.

\section{DISCUSSION}

7. lamblia is the most common intestinal protozoan parasite of humans and the acute to chronic diarrhea which it can cause is often associated with intestinal malabsorption (Farthing, 1992). Even when Giardia is not suspected, cases of 
malabsorption may be due to latent giardiasis, as the organism can be found in the intestine without appearing in feces (Kamath and Murugasu, 1974). However, it has been found that the disaccharidase deficiencies which contribute to the malabsorption of nutrients in giardiasis can occur in infected animal models even in the absence of the live parasite (Belosevic et al., 1989).

In this study, we examined the contribution of the parasite to host malabsorption of disaccharides in giardiasis. Our chromatographic profile of Giardia proteins is supported by work done by Chaudhuri and colleagues (1988), who obtained a similar three-peak separation of the G. lamblia soluble extract, using Sephacryl S-300 gel filtration. Moreover, these researchers found that maximum antigenic activity was associated with their high molecular weight fraction, which eluted in the void volume and should correspond to fraction F1 in this study. Following separation of the G. lamblia soluble extract through Sephacryl S-200 HR chromatography, we were able to identify F1 as the fraction which causes the disaccharidase deficiencies in immune gerbils. The patterns of lactase, maltase and trehalase reductions on days 2 and 4 p.c. in gerbils challenged with $\mathrm{F} 1 \mathrm{mimic}$ those obtained in previous studies with live- and extract-challenged animals (manuscript in preparation). The inability to detect significant differences between control and test groups when measuring sucrase activity may simply be due to the sample sizes. Using a greater number of animals in control and test groups may allow for any differences to be clearly shown, in a statistically significant manner. In addition, there was a threshold effect of fraction F1 on disaccharidase activity and the constituent of F1 involved in the impairments of enzyme activity was found to be heat-stable.

We were able to separate F1 into two fractions, F1a and F1b, again using a Sephacryl S-200 HR column. The use of an eluent containing the dissociating agent guanidine $\mathrm{HCl}$ and the reducing agent dithiothreitol, to disrupt non-covalent interactions and break disulfide bonds in F1, allowed for the further separation of giardial proteins. The ability of fraction F1b to induce similar disaccharidase deficiencies in immune gerbils as when challenging with $\mathrm{F} 1$ or the crude trophozoite extract (manuscript in preparation), indicates that we have isolated a fraction containing the parasite-specific factor that leads to disaccharide malabsorption. Both inter- and intra-strain antigenic variation among G. lamblia isolates have been reported (Smith et al., 1982; Aggarwal and Nash, 1988) and they could contribute to the variability of symptoms seen in giardiasis. Perhaps infections with Giardia strains which possess the relevant protein(s) present in F1b lead to disaccharidase deficiencies in the host. Conversely, an infection with a strain which lacks the key portion of fraction F1b would not affect disaccharide absorption. The complexity of the soluble extract of G. lamblia was demonstrated by the SDS-PAGE protein analysis. The present study revealed that approximately 20 protein bands, ranging from 14 to $130 \mathrm{kDa}$, could be detected. These findings are supported by those of other researchers, who have reported between 20 to 28 protein bands with molecular weights ranging from a low of $10 \mathrm{kDa}$ up to $140 \mathrm{kDa}$ (Moore et al., 1982; Smith et al., 1982; Chaudhuri et al., 1988). We also observed some very faint bands in the region between 130 and $200 \mathrm{kDa}$ (which were concentrated and clearly visible in fraction F1). Such poorly discernable high molecular weight bands in the crude extract have been reported by Smith and colleagues (1982), as well. Given the inability of fraction F2 proteins to affect enzyme activity, it is likely that any protein(s) in F1b responsible for the disaccharidase deficiencies is in the 55 to $200 \mathrm{kDa}$ region.

The role of immune mechanisms in producing malabsorption and intestinal symptoms is unclear. Daniels and Belosevic (1992) found that challenging mice with an extract of G. muris led to more depressed disaccharidase activity in susceptible animals as compared to resistant mice. These authors suggested that this finding could be due to differences in the immune response to different parasite antigens. So selective immune recognition of the relevant parasite antigen, present in fraction F1b, could ultimately result in enzyme deficiencies. The specific type of immune response to F1b which could cause a decline in disaccharidase activities remains unknown. Based on other studies on intestinal damage, the disaccharidase deficiencies in giardiasis may be linked to a mucosal mast cell response to an F1b antigen. Curtis et al. (1990) demonstrated decreased disaccharidase activity in rats following repeated antigen challenge. These enzyme deficiencies were linked to a mucosal mast cell response, as both mast cell proliferation and degranulation were observed. Since the gerbils used in this study were outbred, it is possible that the variation in enzyme activity observed within a test group could be due to varying degrees of a mast cell immune response. It is important to note that there are possible non-immune mechanisms which could also contribute to disaccharidase deficiencies. For example, Giardia trophozoites are known to possess proteinase activity (Hare et al., 1989). A particular proteinase could be present in fraction F1b which affects the enzyme levels as observed. It is apparent, though, that whatever the constituents of F1b which are involved in the disaccharidase deficiencies, they are able to resist the protease activity present in the gut, through an unknown mechanism. 
The present study has dearly implicated fraction F1b of the G. lamblia trophozoite extract in the disaccharidase deficiencies observed in immune gerbils. This fraction acts with a threshold limit on enzyme activity. It seems probable that without the relevant component of F1b, Giardia strains cannot cause disaccharidase deficiencies in infected hosts. However, further investigation of the mechanism(s) of interaction between F1b and the mucosal epithelial cells, including the specific portion of fraction F1b involved in the intestinal dysfunction, is necessary.

\section{ACKNOWLEDGEMENTS}

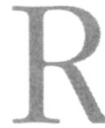

esearch at the Institute of Parasitology is supported by the Natural Sciences and Engineering Research Council of Canada and the Fonds FCAR pour l'aide à la recherche.

\section{REFERENCES}

AggarWal A. \& NASH T.E. Antigenic variation of Giardia lamblia in vivo. Infection and Immunity, 1988, 56, 1420-1423.

Belosevic M., Faubert G.M. \& Maclean J.D. Disaccharidase activity in the small intestine of gerbils (Meriones unguiculatus) during primary and challenge infections with Giardia lamblia. Gut, 1989, 30, 1213-1219.

Brodsky R.E., Spencer H.C. \& Schultz M.G. Giardiasis in American travelers to Soviet Union. Journal of Infectious Diseases, 1974, 130, 319-323.

Buret A., Gall D.G. \& Olson M.E. Effects of murine giardiasis on growth, intestinal morphology, and disaccharidase activity. Journal of Parasitology, 1990, 76, 403-409.

Cevallos A.M. \& Farthing MJ.G. Small intestinal functional damage in experirnental giardiasis is strain-dependent. Gastroenterology, 1991, 102, A602.

Chaudhuri P.P., Pal S., Pal S.C. \& Das P. Studies on Giardia lamblia trophozoite antigens using sephacryl S300 column chromatography, polyaclylamide gel electrophoresis and enzyme-linked immunosorbent assay, in : Advances in Giardia Research. Wallis P.M. \& Hamrnond B.R. (eds), University of Calgary Press, Calgary, 1988, 191-194.

Curtis G.H., Patrick M.K., Catto-Smith A.G. \& Gall D.G. Intestinal anaphylaxis in the rat : effect of chronic antigen exposure. Gastroenterology, 1990, 98, 1558-1566.

DAHLQVIST A. Assay of intestinal disaccharidases. Analytical Biochemistry, 1968, 22, 99-107.

Daniels C.W. \& Belosevic M. Disaccharidase activity in the small intestine of susceptible and resistant mice after primary and challenge infections with Giardia muris. American Journal of Tropical Medicine and Hygiene, 1992, 46, 382-390.

FARTHING M.J.G. New perspectives in giardiasis. Journal of Medical Microbiology, 1992, 37, 1-2.
Gillin F.D. \& Diamond L.S. Axenically cultivated Giardia lamblia : growth, attachment and the role of L-cysteine, in : Waterborne Transmission of Giardiasis. Jakubowski W. \& Hoff J.C. (eds), U.S. Environmental Protection Agency, Cincinnati, 1979, 270-272.

Hare D.F., Jarroll E.L. \& Lindmark D.G. Giardia lamblia characterization of proteinase activity in trophozoites. Experimental Parasitology, 1989, 68, 168-175.

Hoskins L.C., Winawer SJ., Broitman S.A., Gottlieb L.S. \& ZAMCHEK N. Clinical giardiasis and intestinal malabsorption. Gastroenterology, 1967, 53, 265-279.

Kamath K.R \& Murugasu R. A comparative study of four methods for detecting Giardia lamblia in children with diarrheal disease and malabsorption. Gastroenterology, 1974, 66, 16-21.

Keystone J.S., Krajden S. \& Warren M.R Person-to-person transmission of Giardia lamblia in day-care nurseries. Canadian Medical Association Journal, 1978, 119, 241248.

LAEMmLi U.K Cleavage of structural proteins during assembly of the head of bacteriophage T4. Nature, 1970, 227, 680685.

Lowry O.H., Rosebrough NJ., Farr A.L. \& Randall R.J. Protein measurements with folin phenol reagent. Journal of Biological Chemistry, 1951, 193, 265-275.

Mahalanabis D., Simpson T.W., Chakraborty M.L., Ganguli C., BharracharjeE D.K. \& Mukherjee K.L. Malabsorption of water miscible vitarnin $\mathrm{A}$ in children with giardiasis ancl ascariasis. American Journal of Clinical Nutrition, 1979, 32, 313-318.

Moore G.W., Sogandares-Bernal F., Dennis M.V., Root D.M., BECKWITH D. \& VAN VoORHIS D. Characterization of Giardia lamblia trophozoite antigens using polyacrylamide gel electrophoresis, high-performance liquid chromatography, and enzyme-labeled irnmunosorbent assay. Veterinary Parasitology, 1982, 10, 229-237.

NAIN C.K., DUIT P. \& VINAYAK V.K. Alterations in enzymatic activities of the intestinal mucosa during the course of Giardia lamblia infeaion in mice. Annals of Tropical Medicine and Parasitolcgy, 1991, 85, 515-522.

Schmerin MJ., Jones T.C. \& KLeIN H. Giardiasis : association with homosexuality. Annals of Internal Medicine, 1978, 88, 801-803.

SHANDERA W.X From Leningrad to the day-care center - The ubiquitous Giardia lamblia. Western Journal of Medecine, 1990, 153, 154-159.

Smith P.D., Gillin F.D., Kaushal N.A. \& Nash T.E. Antigenic analysis of Giardia lamblia from Afghanistan, Puerto Rico, Ecuador, and Oregon. Infection and Immunity, 1982, 36, 714-719.

Smith P.D., Gillin F.D., SpIRA W.M. \& Nash T.E. Chronic giardiasis : studies on drug sensitivity, toxin production and host immune response. Gastroenterology, 1982, 83, 797-803.

Wright S.G., TOMkins A.M. \& RidLEY D.S. Giardiasis : clinical and therapeutic aspects. Gut, 1977, 18, 343-350.

Accepté le 21 décembre 1994 